\title{
Markers of Vulnerability for Cervical Cancer in HIV-infected Women
}

\author{
Daniele Mary Silva de Brito ${ }^{1}$ \\ Marli Teresinha Gimeniz Galvão² \\ Maria Lúcia Duarte Pereira ${ }^{3}$
}

\begin{abstract}
This study identifies the dimensions and markers of vulnerability among women infected with HIV regarding the development of cervical cancer. A total of 76 HIV-infected women cared for in Fortaleza, CE, Brazil from October 2007 to June 2008 participated in the study. Semi-structured interviews were used to collect socio-demographic, clinical, and sexual data, as well as situations related to health care follow-up and the prevention of cervical cancer. Identified situations were grouped according to the dimensions and markers of vulnerability. HIV-infected women experience different situations linked to individual, programmatic and social dimensions that leave them vulnerable to the development of cervical cancer. The conclusion is that this population is vulnerable to cervical cancer and specific preventive actions are necessary to supply information associated with early detection, improve knowledge, encourage self-care, and improve the quality of health services directed to this population.
\end{abstract}

Descriptors: Vulnerability; Uterine Cervical Neoplasms; Women; HIV; Acquired Immunodeficiency Syndrome.

\footnotetext{
${ }^{1}$ RN, Ph.D. in Nursing, Hospital São José de Doenças Infecciosas, Fortaleza, CE, Brazil. E-mail: danemel6@hotmail.com.

2 RN, Ph.D. in Tropical Diseases. Professor, Universidade Federal do Ceará, Fortaleza, CE, Brazil. E-mail: marligalvao@gmail.com.

${ }^{3}$ RN, Ph.D. in Nursing, Secretaria de Saúde do Estado do Ceará, Fortaleza, CE, Brazil. E-mail: luciad029@gmail.com.
}

Corresponding Author:

Marli Teresinha Gimeniz Galvão

Universidade Federal do Ceará. Faculdade de Farmácia Odontologia e Enfermagem

Departamento de Enfermagem

Rua Alexandre Baraúna, 1115

Bairro: Rodolfo Teófilo

CEP: 60430-160 Fortaleza, CE, Brasil

E-mail: marligalvao@gmail.com, marli@ufc.br 


\title{
Marcadores de vulnerabilidade ao câncer de colo do útero em mulheres infectadas pelo HIV
}

Objetivou-se identificar as dimensões e os marcadores de vulnerabilidade entre mulheres infectadas pelo HIV, para o desenvolvimento do câncer cérvico-uterino. Participaram 76 mulheres, infectadas pelo HIV, de outubro de 2007 a junho de 2008, atendidas em Fortaleza, $\mathrm{CE}$, Brasil. Entrevista semiestruturada propiciou avaliar dados sociodemográficos, clínicos, sexuais e situações relacionadas ao seguimento em saúde e à prevenção contra câncer cérvico-uterino. Os dados possibilitaram o agrupamento de situações indicadas nas dimensões e marcadores de vulnerabilidade. As mulheres infectadas pelo HIV possuem diferentes situações que as tornam vulneráveis ao desenvolvimento do câncer de colo uterino, ligadas às dimensões individual, programática e social. Concluise ser essa população vulnerável ao câncer de colo do útero e serem necessárias ações preventivas específicas, para fornecer informações associadas à detecção precoce da doença, melhoria do nível de conhecimento, estímulo ao autocuidado e melhoria da qualidade dos serviços de saúde destinados a essa clientela.

Descritores: Vulnerabilidade; Neoplasias do Colo do Útero; Mulheres; HIV; Síndrome de Imunodeficiência Adquirida.

\section{Marcadores de vulnerabilidad al cáncer de cuello uterino en mujeres infectadas por el HIV}

\begin{abstract}
Se objetivó identificar las dimensiones y los marcadores de vulnerabilidad entre mujeres infectadas por el HIV, en el caso del desarrollo del cáncer cérvico uterino. Participaron 76 mujeres, infectadas por el HIV, de octubre de 2007 a junio de 2008, atendidas en Fortaleza, estado de Ceará, en Brasil. La entrevista semiestructurada propició evaluar datos sociodemográficos, clínicos, sexuales y situaciones relacionadas al seguimiento en salud y a la prevención contra cáncer cérvico uterino. Los datos posibilitaron el agrupamiento de situaciones indicadas en las dimensiones y marcadores de vulnerabilidad. Las mujeres infectadas por el HIV presentan diferentes situaciones que las tornan vulnerables al desarrollo del cáncer de cuello uterino, ligadas a las dimensiones individual, programática y social. Se concluye que esta población es vulnerable al cáncer de cuello uterino y que son necesarias acciones preventivas específicas, para ofrecer informaciones asociadas a la detección precoz de la enfermedad, mejorar el nivel de conocimiento, estimular el autocuidado y mejorar la calidad de los servicios de salud destinados a esa clientela.
\end{abstract}

Descriptores: Vulnerabilidad; Neoplasias del Cuello Uterino; Mujeres; VIH; Síndrome de Inmunodeficiencia Adquirida.

\section{Introduction}

The emergence of AIDS was a determinant phenomenon in provoking researchers and health professionals to reconsider the concept of risk. Hence, the use of the concept of vulnerability was proposed to be used with people infected with HIV/AIDS as a strategy to overcome the focus of risk, a concept considered inadequate to explain the occurrence of the disease ${ }^{(1-2)}$.
Women infected with HIV are more vulnerable to acquire cervical cancer ${ }^{(3)}$ due to the immunosuppression response induced by HIV, which increases one's susceptibility to opportunistic diseases ${ }^{(4-5)}$. The literature is emphatic in stating that the host's immunosuppression, specifically the woman with HIV, produces changes in cervical lesions with a greater degree of severity(4-5). 
Given the rapid evolution of cervical cancer, this genderspecific disease was the first to be included in the definition of AIDS cases $^{(3)}$.

The Brazilian Ministry of Health recommends screening for cervical cancer through a Pap smear test as a strategy to prevent cervical cancer. This preventive exam has reduced the rates of invasive cervical cancer incidence by up to $90 \%{ }^{(6)}$.

Women infected with HIV are exposed to different situations of vulnerability to cervical cancer. Some that stand out are: lack of knowledge of the population and health professionals concerning cervical cancer; absence of programs or low quality programs directed to the early detection of cancer; limited access to health services; and a lack of referral systems to follow-up $\operatorname{cases}^{(7)}$.

Given the preceding discussion, identifying the level of vulnerability to which HIV-infected women are exposed is required. According to researchers, certain circumstances lead individuals to become more vulnerable in certain situations. In the context of AIDS, the literature presents a model of reference ${ }^{(8)}$ and markers or vulnerability ${ }^{(9)}$.

Vulnerability involves three dimensions or interrelated plans: the individual, programmatic and social dimensions ${ }^{(8)}$. Based on these dimensions, vulnerability markers were proposed to enable the identification of situations of illness referred to in each of the dimensions: individual, programmatic and social ${ }^{(9)}$.

The individual dimension comprises five subgroups related to HIV infection: knowledge and meanings of HIV; personal and relational characteristics; impact of the diagnosis; available resources (personal and experiences that interfere in coping); and coping strategies (practices and behavior). The programmatic dimension includes prevention and care programs and also access to means of control related to the structure and dynamics of the health services' organization and the implementation of actions. This dimension is subdivided into two subgroups: 1) structure and dynamics of the health service's organization and 2) implementation of actions $^{(9)}$.

The social dimension includes: conditions of social government organizations both related and unrelated to AIDS, gender relations, and legal/political apparatus. Such factors directly and indirectly reflect on the vulnerability of individuals infected with HIV.

Given the different dimensions of vulnerability ${ }^{(8)}$ and respective markers, we ask: what is the status of the extent of vulnerability of HIV-infected women regarding the development of cervical cancer?
From this perspective, this study identifies the dimensions and markers of vulnerability among women infected with HIV for the development of cervical cancer cared for by a referral service in Fortaleza, CE, Brazil.

\section{Method}

This is a cross-sectional study. This design permits the investigation of a phenomenon at a given moment. Hence, the presence or absence of exposure and presence or absence of effect in those composing the sample is examined ${ }^{(10)}$. In this case, the vulnerability markers of cervical cancer in women infected with HIV were studied.

The study was developed in the Institute for Cancer Prevention (ICP) in Fortaleza, CE, Brazil. A total of 76 women infected with HIV cared for from October 2007 to June 2008 participated in the study. There were no refusals, thus the sample includes the universe of women infected with HIV cared for in the ICP during the study period.

The following inclusion criteria were adopted: being 18 years old or older, voluntarily consenting to participate in the study, having no previous history of cervical cancer nor having undergone a total hysterectomy.

Data were collected by filling out a semi-structured form, whose variables enable the identification of different aspects of women's lives and which included questions addressing socio-demographic and sexual information, follow-up of HIV infection, and prevention of cervical cancer.

Socio-demographic variables included: age, origin, educational level, Brazil Economic Classification Criteria (BECC), family income, occupational situation, and religion. The variables related to the disease included: stage of infection, category of exposure, result of the $\mathrm{CD}^{+}{ }^{+} \mathrm{T}$ lymphocyte count, antiretroviral use and frequency of visits to an infectious diseases specialist.

The questions addressing sexuality included the variables: number of sexual partners in the previous 12 months, type of partnership, relationship with partner, use of condoms, and knowledge concerning the partner's HIV serology. The variables related to gynecological questions were: menarche, first occurrence of sexual intercourse, time of last preventive exam, whether the exam was performed after the HIV diagnosis, timeframe for performing the preventive exam, access to the health care system to take the exam, where the last exam was performed, information and exam referral by health professionals, history and type of sexually transmitted infections. 
The variables related to the results of the cervical cancer preventive exam (Pap Smear) were: Schiller's test, presence of visible condyloma lesions, and referral for colposcopy after the Pap smear's result. The Brazilian nomenclature was used for the results of the preventive exam in the collection's descriptive diagnosis: cellular atypia in squamous cells and glandular cells.

Each of the answers to both quantitative and qualitative variables were used to develop the study's results. Based on the literature, a meaning expressing or indicating situations of vulnerability was attributed to each result ${ }^{(9,11)}$. Hence, a list of conditions - situations of vulnerability - was developed and distilled into a final list of circumstances to which women with HIV were exposed.

Such situations were then grouped and classified in accordance with the literature, identifying the obtained vulnerability markers that were related to the development of cervical cancer. The vulnerability markers followed the formulations of the model conceived and proposed by a researcher in Brazil(11). Then the markers were subdivided into three dimensions ${ }^{(9)}$ :

- individual dimension: personal and relational characteristics, knowledge of and meanings attributed to HIV, impact of the diagnosis, available resources (personal and experiences that interfere in coping) and coping strategies;

- programmatic dimension: structure and dynamics of the health service's organization and the implementation of actions;

- social dimension: material conditions of existence, ideology and culture.

Based on the literature, some markers were not included because they were not identified with the study's variables such as: available resources and coping strategies. Other situations however, were considered situations of vulnerability for cervical cancer and were added to the study due the perceptions reached during the study, e.g. the revelation that these women were afraid of meeting familiar people in the health service unit. This circumstance was classified in the individual dimension. Another situation involved the inappropriate physical structure of the health units different from what is required in the programmatic dimension. This situation referred to rooms with acoustic propagation and that conferred little privacy to women during consultations.

The study followed all the recommendation of Resolution 196, October $19^{\text {th }} 1996$, National Council of Health, concerning studies involving human subjects.
The Research Ethics Committee at the São José Hospital of Infectious Diseases approved the project (protocol No. 022/2007). All the participants received clarification about the study and signed free and informed consent forms.

\section{Results}

A brief description of the participants is presented for a better understanding of the different aspects of the dimensions and vulnerability markers described throughout the paper. The average age of the 76 participants was 37.4 years old and $42.1 \%$ lived with a partner; $90.8 \%$ of them were infected with HIV through sexual exposure; $76.3 \%$ had already developed AIDS; and $94.7 \%$ practiced some religion. In relation to their work situation, $51.3 \%$ did not have a paid job; $65.8 \%$ had up to a primary school education; almost all of the women $(92.2 \%)$ belonged to the lower class (Classes D and $\mathrm{E}$ according to BECC) and $73.3 \%$ reported a family income from one to four times the minimum wage.

The results of the $\mathrm{CD} 4^{+} \mathrm{T}$ lymphocyte count from the three previous months showed that the lymphocytes of $40.8 \%$ of them were below 350 cells $/ \mathrm{mm}^{3}$.

In relation to the use of condoms, $84.3 \%$ use them with stable partners; $47.4 \%$ had already had casual partners but half of them did not use condoms in these relationships. Paid sexual intercourse were reported by $10.5 \%$ of the women; $12.5 \%$ of these did not use condoms.

The last cervical cancer preventive exam was performed less than one year previously by $44.8 \%$ of the women, while $51.3 \%$ had it more than two years ago, and 3.9\% had never had the exam.

A total of $31.6 \%$ of the women did not take the preventive exam after their HIV diagnosis. In relation to its frequency, $3.9 \%$ had it every six months, $44.8 \%$ yearly, and $5.3 \%$ had the exam every two years; $46 \%$ of the women were not able to report the precise interval between exams.

Access to the exam was considered difficult by $85.5 \%$ of the participants. This fact is related to difficulties in scheduling the exam, financial and transportation difficulties, the poor quality of health services, and a long waiting time to schedule a medical appointment.

The investigation concerning the women's history of sexually transmissible infections revealed that $40.8 \%$ of them had a previous infection. A total of $46.1 \%$ reported they were not aware of the need to take the exam more frequently, even given the HIV. 
Figure 1 presents the markers of vulnerability and the situations grasped by the different analyses obtained through the characteristics and conditions of women infected with HIV. Such data enable the description of the vulnerabilities to which these women were exposed in relation to the development of cervical cancer. These were concomitantly classified according to the literature ${ }^{(9)}$ in the individual, programmatic and social dimensions.

The markers observed in the individual dimension are related to three aspects: personal and relational characteristics; knowledge and meanings, and impact of the diagnosis. In consonance with that proposed in literature concerning the programmatic dimension, the markers of the structure and dynamics of the health service's organization and implementation of actions were identified. In the social dimension, the markers grasped in the data evaluation were those concerning material conditions of existence, ideology and culture (Figure 1).

\begin{tabular}{|c|c|c|}
\hline Dimensions & & Markers of vulnerability \\
\hline \multirow{13}{*}{ Individual } & \multirow{5}{*}{ Knowledge and meanings } & Insufficient knowledge concerning the need to have the cervical cancer preventive exam \\
\hline & & $\begin{array}{l}\text { Lack of knowledge concerning vulnerability to cervical cancer given the association between } \\
\text { immunossupression (HIV) and cervical cancer }\end{array}$ \\
\hline & & Discontinuity of the cervical cancer preventive screening test \\
\hline & & Inappropriate interval between the cervical cancer preventive tests \\
\hline & & Not having the exam after HIV diagnosis \\
\hline & \multirow{6}{*}{$\begin{array}{l}\text { Personal and relational } \\
\text { characteristics }\end{array}$} & Low educational level \\
\hline & & Home environment with reduced family income \\
\hline & & Lower class \\
\hline & & Few paid jobs \\
\hline & & Inconsistent use of male condom with stable, casual and commercial partners. \\
\hline & & Acquisition of other sexually transmissible infections \\
\hline & \multirow{2}{*}{ Impact of the diagnosis } & Neglect in the evaluation for diagnosis and control of cervical cancer \\
\hline & & Fear of meeting familiar people in the health service \\
\hline \multirow{14}{*}{ Programmatic } & \multirow{8}{*}{$\begin{array}{l}\text { Structure and dynamics of the } \\
\text { health services' organization }\end{array}$} & Service's irregular availability to perform the cervical cancer test \\
\hline & & $\begin{array}{l}\text { Lack of specialized referral service for following-up HIV, of professionals to collect material for } \\
\text { the preventive exam and gynecologists to perform such activity }\end{array}$ \\
\hline & & $\begin{array}{l}\text { Lack of cooperation with other health services (infectious diseases services and referral } \\
\text { services for cervical cancer) }\end{array}$ \\
\hline & & Inexistent protocol for cytological follow-up of women with HIV \\
\hline & & $\begin{array}{l}\text { Insufficient dissemination of information concerning the importance of the cervical cancer } \\
\text { screening test }\end{array}$ \\
\hline & & Difficult access and lack of cooperation among health units \\
\hline & & Lack of health educational activities to prevent cervical cancer \\
\hline & & Lack of health prevention activities during the HIV infection \\
\hline & \multirow{6}{*}{ Implementation of actions } & $\begin{array}{l}\text { Non-compliance of the protocol concerning the preventive test established by the Ministry of } \\
\text { Health to follow-up HIV-infected women }\end{array}$ \\
\hline & & Predisposition for late diagnosis of cervical cancer \\
\hline & & Insufficient guidance and referrals to specialized services in cervical cancer \\
\hline & & Clinical intervention only; interventions do not include the determinants of users' behavior \\
\hline & & $\begin{array}{l}\text { Absence of appropriate physical structure (a place) to meet the women's demands so they } \\
\text { can share their feelings }\end{array}$ \\
\hline & & $\begin{array}{l}\text { Lack of knowledge of other needs and health problems stemming from AIDS or others such } \\
\text { as cervical cancer, which go beyond biological and clinical characteristics }\end{array}$ \\
\hline \multirow{3}{*}{ Social } & \multirow{2}{*}{ Material conditions of existence } & Insufficient conditions to live with health-related quality of life in the presence of HIV \\
\hline & & Insufficient access to social devices \\
\hline & Ideology and culture & Daily experiencing gender differences \\
\hline
\end{tabular}

Figure 1 - Markers of vulnerability to cervical cancer observed in 76 HIV-infected women

\section{Discussion}

A vulnerable individual has no means to protect him/herself and has no access to health care, education, work, source of income or housing, in addition to not being free to choose(11). 
The studied women belong to this vulnerable population. Hence, even though they have guaranteed rights such as resources for improving their health, they are deprived of the guarantee of ample prevention against gynecological cancer because they are not informed, do not know about the need to systematically have not had a preventive exam, and the service in which they are cared for does not totally comply with its function of specialized care for health follow-up. Therefore, vulnerability ranges from the individual to the programmatic dimensions.

Individual vulnerability refers to individual preventive actions in the face of a situation of risk. It involves aspects related to personal characteristics, emotional development, the perception of risk and attitudes directed to the adoption of measures for selfprotection, personal behavior in the face of sexuality, and also acquired knowledge ${ }^{(12)}$. Most of the studied women had inaccurate and insufficient knowledge concerning preventive Pap smear exams; they did not have one with the appropriate frequency, nor were they aware of the relationship between immunosuppression and cervical cancer. Additionally, a high number of women did not receive the exam after receiving the diagnosis of AIDS.

Knowledge and meaning can influence conduct after the diagnosis, treatment prescription, coping strategies, and treatment adherence ${ }^{(9)}$. However, understanding what influences vulnerability is necessary in order to propose changes in behavior to reduce vulnerability. In this context, this study showed that the inaccurate or insufficient knowledge of women concerning the Pap smear test hinders self-care and also increases their vulnerability to the development of cervical cancer.

Concerning the participants' personal and relational characteristics, the studied population experiences different situations that increase vulnerability, such as: a low educational level, living in a family environment with limited income resources, poor inclusion in the formal job market, in addition to certain means of individual protection such as the inconsistent use or lack of male or female condoms with sexual partners, whether stable or not.

Personal characteristics configure conditions of vulnerability and social exclusion such as living with a low educational level and low family income, unemployment and poor living conditions ${ }^{(9)}$. According to this study, such situations result in greater difficulty accessing basic services such as education and health, which can aggravate an individual's condition, interfering in his/her health while increasing his/her vulnerability to illness.
As observed, vulnerability is a dynamic process established by the interaction of elements that compose it, such as age, race, ethnicity, poverty, schooling, social support and the presence of health problems. Such elements were identified in this study. However, the state of vulnerability is defined not only by characteristics intrinsic to the individual such as gender and age but also by other conditions acquired over the course of life or which result from lifestyle, development of strategies, and the ability to cope with trauma and disease ${ }^{(8)}$. From this perspective, we believe that each individual has a threshold of vulnerability, which when crossed, results in illness.

Knowledge and behavior have very diversified meanings and repercussions in the lives of people, depending on the always unique combination of personal characteristics, context of life, and interpersonal relationships established in daily life ${ }^{(9)}$.

In relation to the impact of the diagnosis on women, this study revealed that they have difficulty acknowledging and identifying themselves as HIVinfected individuals, often demanding confidentiality concerning their HIV-positive status. This fact led the patients themselves to neglect their health care followup even before they discovered they were infected with HIV, a fact exemplified by the non-realization of the preventive exam. Such neglect can increase vulnerability to the development of cervical cancer. Hence, even if keeping the diagnosis confidential protects against prejudice, it also impedes the individual's reception of support, making her even more vulnerable to the development of cervical cancer ${ }^{(9,13)}$.

Although all women are potentially vulnerable to AIDS and the development of cervical cancer, there are some groups of women particularly subject to certain conditions that make them more vulnerable and, therefore, more likely to develop the disease.

Lack of knowledge or inaccurate knowledge lead women to be negligent and not realize how vulnerable they are to cervical cancer. The fact that health professionals focus on the disease from a medicalization perspective and these women's lack of empowerment concerning their health contribute to a situation in which women are seen and see themselves in a fragmented way. Therefore, health professionals should identify the conditions, characteristics and situations that enable protection and empowerment of people against illness, contributing to the reduction of vulnerability of HIV-infected women to cervical cancer. 
Various aspects contributing to increased vulnerability to cervical cancer were observed in the programmatic dimension that addresses the structure and dynamics of the health service's organization. Such situations include the absence of gynecological services to implement cervical cancer preventive interventions in referral hospitals, irregular availability of other services to perform the cervical cancer exam, lack of cooperation with other health services (infectious diseases services and cervical cancer referral services), insufficient dissemination of information concerning the importance of the Pap smear, difficulty scheduling appointments in health units, and the absence of health education interventions administered in waiting rooms designed to prevent cervical cancer.

A study conducted in the state of São Paulo, Brazil, reported similar data in relation to health services such as: fragmented care, a long waiting time, limited teamwork and the lack of qualification among professionals, an insufficient number of slots to meet demand, a lack of integration among the actions developed, and insufficient dissemination of information concerning the importance of an early diagnosis, among others ${ }^{(9)}$.

The relationship between quality of access to health services and lack of cooperation among these services with institutions of other fields is defined as a marker of vulnerability. This lack of cooperation hinders the implementation of preventive actions targeting cervical cancer among women infected with HIV, because they have to search for another service in order to receive specific care. According to the plan designed by the Ministry of Health, specialized care services should include prevention against gynecological cancer in health promotion actions.

For the most part, the inattention of women with HIV leads to a situation in which care, guidance, and early detection of diseases are neglected. Hence, one should acknowledge that the health service might contribute to the vulnerability of HIV-infected women, thereby reducing their chances of obtaining an early diagnosis of cervical care.

The programmatic component of vulnerability implies the need for financial investments in the health and education sectors, in promoting the education of human resources to perform prevention, diagnosis and care actions, and in the development of programmatic and inter-sector public policy actions. Mediation between health professionals and patients is desirable to promote the mobilization of society to develop each individual's health potential and demand their rights to access health care in its most varied aspects ${ }^{(9)}$.
Based on what was observed in the programmatic dimension, specialized health services need to be increased as does the availability of resources to enable greater coverage of early cervical cancer diagnosis in order to promote women's quality of life.

The social dimension encompasses a set of characteristics associated with the political, economic and socio-cultural contexts that characterize individual risk, making explicit the undeniable relationships among health problems and poverty, low salaries, inadequate education, among others ${ }^{(9)}$. Vulnerability in the material conditions of existence and ideology and culture were highlighted in this study, and conditions necessary to enable a healthy life were found to be insufficient, as well as uncovering insufficient social devices and poor access to existing devices capable of performing the preventive cervical cancer exam. Situations such as poverty, low salaries, low educational level, difficulty accessing health services, among others, and that directly interfere in the prevention of cervical cancer were identified.

There are also situations of economic, social and cultural inequality in the context of the lives of these women from lower classes, which generate vulnerability to illness ${ }^{(14)}$. These social processes inter-relate and hinder self-care. Hence, the development of health care actions directed to HIV-infected women based on the vulnerability markers enhances the possibilities of understanding and reflecting upon situations that may lead to either greater or lesser vulnerability to cervical cancer.

\section{Conclusion}

In general, women presented different contexts of vulnerability to the development of cervical cancer in terms of socio-demographic, epidemiological, clinical, sexual and gynecological factors, in the individual, social and programmatic dimensions.

Different data and information enable the planning of actions based on the concept of vulnerability, valuing information and the modification of individual, programmatic and social behavior, aiming to reduce the chances of HIV-infected women developing cervical cancer. It is urgent that health professionals promote means to strengthen the use of information by this population and its comprehension skills. Such means should enable the transformation of this population's practices in relation to cervical cancer and also promote appropriate access to the diverse services to promote and protect health. 
It is worth noting that it is the role of health services, regardless of the level of care, and especially HIV/AIDS referral services, to ensure integrality of health care actions directed to HIV-infected women. From this perspective, it is also important to make available gynecological monitoring programs that provide the Pap smear exam as recommended by the different health control agencies.

\section{References}

1. Mann J, Tarantola DJM, Netter TW. A Aids no mundo. Rio de Janeiro: ABIA: IMS/UERJ; 1993.

2. Ayres JRCM, França I Júnior, Calazans GJ, Saletti HC Filho. O conceito de vulnerabilidade e as práticas de saúde: novas perspectivas e desafios. In: Czeresnia D, Freitas CM, organizadores. Promoção da saúde: conceitos, reflexões, tendências. Rio de Janeiro: Fiocruz; 2003. p. 117-39.

3. Centers for Disease Control and Prevention (CDC). United States Department of Health and Human Services. National Institutes of Health. Treatment of opportunistic infections. Washington: DCC; 2006.

4. Rachid M, Schechter M. Manual de HIV/AIDS. 8.ed. Rio de Janeiro: Revinter; 2005.

5. Beskow AH, Emgelmark MT, Magnusson JJ. Interation of host and viral risk factores for development of cervical carcinoma in situ. Int J Cancer. 2005;117(4):690-2.

6. Ministério da Saúde (BR). Secretaria de Atenção à Saúde. Departamento de Atenção Básica. Controle dos cânceres do colo do útero e de mama. Brasília: Ministério da Saúde; 2006.

7. Bradley J, Barone M, Mahe C, Lewis R, Luciani S. Delivering cervical cancer prevetion services in lowesouce settings. Int J Gynaecol Obstet. 2005;89(Suppl. 2):21-9.

8. Ayres JRCM. Epidemiologia, promoção da saúde e o paradoxo do risco. Rev Bras Epidemiol. 2002;5(supl 1):28-42.

9. Takahashi RF. Marcadores de vulnerabilidade a infecção, adoecimento e morte por HIV e AIDS. [Tese Livre-Docência]. São Paulo (SP): Escola de Enfermagem da Universidade de São Paulo; 2006.

10. Bastos JLD, Duquia RP. Um dos delineamentos mais empregados em epidemiologia: estudo transversal. Scient Med. 2007;17(4):229-32.

11. Saldanha AAW, Figueiredo MAC, Coutinho MPL. AIDS: trajetória e tendências da epidemia - a legitimação de um universo simbólico. In: Coutinho MPL, Saldanha AAW. Representação social e práticas de pesquisa. João Pessoa: UFPB; 2005. p. 153-72.
12. Nichiata LYI, Bertolozzi MR, Takahashi RF Fracolli LA. A utilização do conceito "vulnerabilidade" pela enfermagem. Rev. Latino-Am. Enfermagem. 2008;16(5):923-8.

13. Carvalho CML, Galvão MTG. Enfrentamento da aids entre mulheres infectadas em Fortaleza-CE. Rev Esc Enferm USP. 2008;42(1):90-7.

14. Souza KV, Tyrrell MAR. Os fatos e atos relacionados ao (difícil) exercício dos direitos sexuais e reprodutivos: recortes, o processo de viver de um grupo de mulheres de classes populares. Texto Contexto Enferm. 2007;16(1):47-54.

Received: June $30^{\text {th }} 2010$ Accepted: Mar. $17^{\text {th }} 2011$ 